\title{
The United Nations Force Intervention Brigade: Wither the SADC/ICGLR Synchronised Peace Support Efforts in the Eastern Democratic Republic of Congo Recurring Conflict?
}

\author{
Engelbert Abel Rugeje \& Sadiki Maeresera \\ University of Kwazulu-Natal \\ King George V Ave, Durban, 4041, South Africa \\ rugejea@gmail.com; maeresera@ukzn.ac.za \\ DOI: https://doi.org/10.32890/jis2016.12.5
}

\begin{abstract}
From the time it deployed in the eastern DRC in 2013 up to the first quarter of 2016, arguably no much tangible progress has been made by the United Nations Force Intervention Brigade (UN FIB). The security situation in eastern Congo continues to be unstable. This instability has serious direct security threats and spillover effects on respective neighbouring countries that are either part of the Southern African Development Community $(S A D C)$ or the International Conference on the Great Lakes Region (ICGLR). There are certain constraints that the FIB has continued to encounter in the context of regional and international political and strategic dynamics surrounding eastern Congo recurring conflict. This paper argues that one of the contributing factors behind the challenges encountered by the UN Force is the fact that both the ICGLR and the SADC efforts at enhancing peace enforcement in the eastern DRC have been overshadowed by the self-interests of international actors. Arguably, this scenario has impacted negatively on the ICGLR/SADC synchronised efforts towards the effectiveness of the FIB. The paper makes some recommendations on how best to attain sustainable synergy between the ICGLR and $S A D C$ in order to enhance the strategic and operational efficiency and the effectiveness of the UN FIB in the eastern Congo conflict.
\end{abstract}

Keywords: Democratic Republic of Congo, The United Nations Force Intervention Brigade, Synchronised Peace Support Efforts, The International Conference on the Great Lakes Region, Southern African Development Community.

\section{Introduction}

Violent recurring armed conflict has engulfed the eastern Democratic Republic of Congo (DRC) for more than two decades. The conflict, which has claimed over three million people, mostly women and children, has mostly been caused by a number of factors. These range from national to regional and international dynamics especially competition for the exploitation of the vast natural resources which are on demand in the international market. The United Nations Force Intervention Brigade (UN FIB) was deployed in eastern Congo in addition on the United Nations Observer Mission in Congo (MONUSCO) which has been operating in the DRC for more than two decades. This paper makes an analysis of the 
constraints to the UN FIB's effectiveness in the eastern DRC. The analysis will be made in the context of interrogating how the quest for synchronised peace enforcement efforts by the ICGLR and SADC have been compromised the respective self-interests of international actors. A brief overview of the rationale behind the formation of the Force will be given. The constraints that have been encountered (and continue to be encountered) by the FIB in the context of regional and international political and strategic dynamics will be discussed with specific reference to the eastern Congo conflict. Considering that the eastern Congo is an area of peace and the security responsibility of both the SADC and the ICGLR, the paper will also examine how synchronised efforts between the two have been affected by the interests of international actors, thereby impacting negatively the strategic and operational success of the FIB as a peace enforcement mechanism. Suggestions will be made on how (in the context of the FIB) synchronised peace support efforts by the SADC and the IGGLR will assist in the attainment of durable peace in eastern Congo.

\section{A Brief Background of the Eastern DRC Recurring Conflict}

The African continent has seen a marked increase in political instability and chaos since the dawn of the so-called post-Cold War era, owing to unfavourable economic conditions combined with internecine ethnic-inspired conflicts. In a way, what has been happening in the continent for over two decades seems to resonate what Basil Davidson (I992) has termed the 'curse of the nation state'. The result has been a rise in the scale and frequency of interstate wars, civil wars and communal violence. One such state that epitomises this characterisation has been the Democratic Republic of Congo (Tull, 2010). The Congo state has experienced general disintegration and turmoil during and after the colonial era. It was ruled as a personal property by King Leopold II. Again during the era of Joseph Desire Mobutu the country was also ruled on a more or less basis. The current upheavals unfolding in the DRC in general and eastern Congo in particular since the 1990s, are marked by diverging interests between local communities and central power with foreign backers supporting these countervailing forces. In essence, the case of the DRC indicates the challenge of the state building project in some African countries.

In view of the above characterisation of the $\mathrm{DRC}$, it is no wonder then, that the country has the singular 'dishonour' of being a recipient of multiple United Nations peacekeeping formations, unleashed on this failing state as potential sources of hope (Gibbs, 2000). With this in mind, in the long run, the conception of peacekeeping has gradually broadened in scope (Tull, 2008). These newer conceptions of peacekeeping in the post-Cold War, also known as 'wider peacekeeping' or 'muscular peacekeeping' have a clearly interventionist agenda (see Crocker in Hirsch \& Oakley, 1995; Ruggie, 1996; Tull, 2008). Increasingly, peacekeepers are expected to intervene in certain conflicts, with some measure of force when necessary, in order to enhance human security. Meanwhile, the United Nations' activities in the Democratic Republic of Congo (DRC) and more so in the eastern part of the country in the aftermath of the regional conflict that afflicted the DRC between 1998 and 2003 have many unique characteristics and raise a number of complex questions. More importantly, 
the presence of the UN through MONUSCO highlights the need for military assistance on the grounds that the national territory of the DRC was and is threatened by the unsolicited presence of local and foreign troops on the soil of the country. Likewise, the various armed rebel groups and militia do not enjoy the support of the overwhelming majority Eastern Congolese population. Some view them as groups engineered by the conspiracy between international/regional actors and small groups of Congolese leaders.

\section{The Rationale Behind the Formation of the UN Force Intervention Brigade}

The UN FIB was formed under the United Nations Security Council (UNSC) Resolution 2098, which authorised the deployment of the force in March 2013 (Cammaert, 2013) ${ }^{1}$. The brigade was to be utilised as an offensive combat force under the United Nations Organisation Stabilisation Mission in the Democratic Republic of Congo (MONUSCO) as indicated by Sheeran and Case (2014) ${ }^{2}$. The deployment of the FIB also came as a result of the attack and capture of the eastern DRC city of Goma by the March 23 (M23) rebels in November $2012^{3}$. Only three SADC countries, namely Malawi, Tanzania and South Africa, have a contingent each that make up the Intervention Force. As indicated by Hoffstatte (2014) ${ }^{4}$, the FIB comprises of 3 infantry battalions, an artillery regiment, an elite special force and a reconnaissance company. Its mission has been to protect civilians against human rights abuses and neutralising the armed militias operating in eastern Congo $^{5}$. The Force was established as a result of a considerable number of reports which highlighted the changing dynamics of the eastern Congo conflict, especially the perpetration of violence against unarmed civilians and serious human rights violations, including sexual and gender-based violence (Mutisi, 2015) ${ }^{6}$. However, there have been criticisms levelled against the Force in terms of its mandate, which compromises the impartiality and neutrality of the UN peacekeeping operations (The International Coalition for the Responsibility to Protect, 2015) ${ }^{7}$. Further criticism against the FIB revolves around the fact that by engaging in combat activity, the force becomes a part to the eastern Congo conflict. It is open to considerable doubt whether, in the existing law of war, an international Force which is part of a subsidiary organ of the United Nations can be belligerent to which the customary law of war applies. This raises the fundamental question of peacekeeping impartiality, that is, "the extents to which peacekeepers act in the interests of international peace and security, rather than the interests of specific states or other external actors" (Gibbs, 1960).

However, it should be realised that despite the criticisms levelled against the FIB, MONUSCO has relatively struggled to protect the civilians against all forms of human rights abuses from the militias. In fact there have been allegations of human rights abuses (such as rape and other forms of women abuses) against the peacekeeping troops under MONUSCO. These abuses are alleged to have been carried out before the deployment of the FIB in 2013 (Vogel, 2013) ${ }^{8}$.

The FIB's formation and its modus operandi can also be understood in the context of the peace, security and cooperation framework for the DRC and the region. The framework was 
signed in Addis Ababa, Ethiopia, by member countries from the ICGLR, the SADC and notable representatives from the AU and the UN. In an effort to realise the effectiveness of the framework, the ICGLR proposed the formation of a Neutral Intervention Force ${ }^{9}$. The objective of having such a force was to utilise it in conducting counter offensive military operations against armed groups operating in the eastern part of the Congo, neutralise and disarm the armed militias, as well as protecting civilians against human rights abuses ${ }^{10}$. In order to comprehend the complexity surrounding the task of neutralising the various armed groups in eastern Congo, it is prudent to briefly take stock of the notable militias that operate in north and south Kivus.

More importantly, the formation of the UN Force Intervention Brigade consisting respective army units from South Africa, Tanzania and Malawi can also be seen in the context of developing the notion of African peacekeeping. As indicated by Gibbs (2000) the possibility of African peacekeeping has in fact elicited considerable interest in Africa as well as in the Western world. This may be another route of engendering impartial peacekeeping by enabling Africans to bring solutions to African challenges. A number reasons support the concept of African peacekeeping. First, African peacekeeping forces have higher levels of legitimacy, particularly in the African continent, than say, externally directed or driven peacekeeping forces. Furthermore, African peacekeeping might prevent direct Western domination, of the sort that occurred in Somalia under UNISOM when the US sought to direct everything. Based on the assessment of the former UN Secretary-General, Boutros Boutros-Ghali, as revealed in his memoirs released in 1998 as cited by Gibbs (2000), when the US decides to participate in any major military operation including peace support efforts, it insists on running the show. It is equally clear, then, that major powers like the US simply want to use the UN as a 'fig leaf'. Another advantage of African peacekeeping is that it avoids the persistent notion of neo-colonialism as was the case with France's Operation Turquoise in Rwanda. This French intervention attracted condemnation as it was widely seen as an outdated intervention by a colonial power eager to reassert primacy in its francophone sphere of influence. Even the participation by a token number of troops from several of France's African allies and partners did little to water down or dampen the neocolonial posture of the intervention. Like the US hegemonic designs, neo-colonial ventures like Operation Turquoise are equally problematic.

Notwithstanding these advantages, it is not clear that African peacekeeping forces would prove any more effective or impartial than those organised by powerful external actors. As noted by Jackson (2007) it is astonishing how little is known by the Africans about the extensive Western-sponsored military initiatives currently under way across the continent. These kinds of partnerships between African and Western governments always raises the spectre of 'he who pays the piper calls the tune'. Furthermore, African peacekeeping must be aware of the dangers of reproducing hegemonic influence, albeit, at regional level. Available evidence suggests that the regional hegemons have a tendency of dominating such peace support initiatives, in a manner reminiscent of the US domination of peacekeeping in Somalia in the 1990s. According to James (1990) as cited in Gibbs (2000), African peacekeeping must avoid the trap of 'backyard peacekeeping operations', where the 
The United Nations Force Intervention Brigade: Wither the SADC/ICGLR Synchronised Peace Support Efforts in the Eastern Democratic Republic of Congo Recurring Conflict?

peacekeepers and the 'host' state are all from the same general region. Such operations are continuously under threat of influence from an adjacent regional power which may impede impartial peacekeeping.

\section{Legal Dynamics of the Formation of the UN Force Intervention Brigade}

From a legalistic perspective, the FIB was in point of fact established by the SecretaryGeneral under the authorisation of the Security Council contained in its resolution 2098 of March 28, 2013, which authorised the deployment of the military formation in March 2013. As can be seen, the Brigade, therefore, is, as a matter of law, a subordinate organ of the Security Council set up by that organ under the powers conferred upon it by Article 29. Hence, the FIB acts entirely under the command of the Secretary-General, acting, in his turn, on behalf of the Security Council and the Organisation. It is this legal basis which determines, in large part, the distinctive characteristics of the UN Force Intervention Brigade in Congo which in essence is the first UN peacekeeping formation with a mandate to carry out targeted offensive operations to neutralise armed groups that pose a threat to the state and human security in eastern DRC.

Just like its earlier predecessor, the UN International Force in Congo set up in 1960 (Draper, 1963), a critical legal consequence flow from the fact that the immediate legal parentage of the Force is based on Article 29, and from its remoter connection with Article 40. In other words, the FIB can have no more extensive functions than those conferred upon the Security Council by the UN Charter. This status of the FIB in Congo is separate and distinct from that of other previous peacekeeping formations. The precedent afforded by the FIB is in every way closer to that of the earlier United Nations International Force in the Congo of 1960, since both peacekeeping operations took place within the framework and limitations of the functions of the Security Council as opposed to those of the General Assembly. Bearing in mind that the Security Council, being the organ of the United Nations under Article 24 of the Charter, bears the primary but not exclusive responsibility for maintaining international peace and security, it is scarcely surprising that the FIB as a subsidiary organ of the Council has found itself engaged in active military operations in the course of carrying out its functions. Such would seem to be the logical result of its legal parentage.

\section{The Complexity of Neutralising and Disarming Armed Militias in the Kivus}

The north and south Kivus continue to be a haven of a considerable number of armed militias. The proliferation of these groups makes it complicated for the UN FIB to undertake one of its tasks, which is neutralising and disarming these multiple armed groups operating in eastern Congo. The situation is even made worse by the fact that these militias have goals and objectives, let alone intentions which are diverse and very complex. The armed militias have different origins and purported grievances. The multiplicity of these militia groups thus makes it challenging for the FIB to also implement the DDRRR successfully. 


\section{The M23 Armed Rebel Group and Its Allied Militias}

The M23 rebel group came into existence in April 2012 when a considerable number of FARDC (Congolese army) troops mainly of Tutsi origin, led by Gen Bosco Ntaganda, mutinied. Reasons for the mutiny revolved around poor working conditions such as paltry salaries, among others. The M23 had its allied group, the Mai Mai Hilaire (Union pour la Réhabilitation de la Démocratie du Congo - URDC) which was led by "Brigadier General" Paluku Kombi Hilaire, a FARDC defector. Another M23 collaborating militia group, Raia Mutomboki, ("outraged citizens"), was regarded as the largest armed body in South Kivu. It was led by a Congolese army defector, Pastor Jean Musumbu. It is believed that this group was formed in response to FDLR massacres. Raia Mutomboki comprised various armed militia groups which were headed by local leaders and Congolese army deserters ${ }^{11}$.

\section{The Mai Mai Sheka and Other Collaborative Groups}

The Mai Mai Sheka was formed in 2009 by long-time minerals businessman Ntabo Ntaberi Sheka in north Kivu's Walikale Territory. This militia rebel group has 150-180 men who are mainly Congolese army deserters, youths and, to some extent, child youths. There has been some alleged collaboration between Sheka with ex-CNDP (subsequently M23 leader) Gen Bosco Ntaganda. The Sheka fighters are recruited mainly from the Batembo, Bahunde and Bayanga communities. The militia rebel group is reportedly active in southern Masisi Territory (North Kivu). The rebel group claims to be protecting "indigenous" interests from purportedly foreign Rwandophone groups. In reinforcing the atrocities committed by the Mai Mai Sheka in eastern DRC, thereby fuelling the conflict, the International Coalition for Responsibility noted that:

"The Mai-Mai Sheka has contributed to the violence in the DRC by attacking not only civilians, but also UN peacekeepers. The group, which was formed in 2009 by mineral resources businessmen, was also involved in the increased October 2013 rebel conflict experienced in eastern DRC. Earlier, the Mai-Mai Sheka had gained notoriety for an exceptionally violent episode of sexual violence in 2010. Indeed, during the period of 30 July to 4 August 2010, the mass rape of more than 240 people was carried out in eastern Congo by members of both the Rwandan FDLR and the Mai-Mai Sheka rebels. In addition, the homes and shops of many of those who were raped were also looted. These crimes occurred within miles of the UN peacekeepers' base, but the UN Organization Stabilization Mission in the Democratic Republic of the Congo (MONUSCO) was unable to protect the Congolese civilians. The UN headquarters only became aware of the violence days later, when the International Medical Corps, which was charged with treating many of the victims of these attacks, first reported it. Atul Khare, then UN Assistant Secretary-General for Peacekeeping Operations, acknowledged the failure of the UN by stating that "our actions were not adequate, resulting in unacceptable brutalization of the population of the villages in the area. We must do better." The UNSC also urged for the "swift and fair prosecution of the perpetrators," and called for the enhancement of MONUSCO's "interaction with 
the civilian population. Because of the mass rapes, the UN Special Representative of the Secretary-General on Sexual Violence in Conflict, Margot Wallström, stated that there was the potential for victims to be attacked in the future by the Armed Forces of the DRC (FARDC), as "there is already some information from MONUSCO peacekeepers on the ground that rapes, killings and lootings have been perpetrated by FARDC soldiers." 12

In addition to the Mai Mai Sheka, there is also the Local Defence Forces Busumba (LDF) Erasto Ntibaturama, an influential ethnic Hutu figure in northern Masisi (North Kivu), established LDF, which had over 50 mainly Hutu men, in 2005. According to the Enough Project, the LDF militia group is reportedly allied to the M23. Besides the LDF, there is also the Union des Patriotes Congolais pour la Paix (UPCP/FPC). This militia group was formed in 2012. It is a coalition of the Mai Mai groups and defectors from the Congolese army which was led by "General” Kakule Vasaka Sikulikyolo Lafontaine. The LDF comprises 500-600 fighters who are mostly from the ethnic groups. These militias operate in the areas around Lubero in North Kivu ${ }^{13}$.

\section{Mouvement d'Action pour le Changement (MAC)}

There is also the Mouvement d'Action pour le Changement (MAC) whose aim is countering M23's advance into Masisi. The group was formed by a faction of locals who fell out with Ntaganda (after his mutiny in FARDC to form M23. MAC is led by Lt-Col Bwira, a former FARDC commander from the Hunde community. It has about 300 troops who are mainly from the Hunde and Nyanga ethnic groups ${ }^{14}$.

\section{The Mai Mai Morgan and Its Allies}

In addition to the above mentioned groups, there is also the Mai Mai Morgan rebel militia which is led by Paul Sadala alias Morgan. The group operates in the Mambasa and Bafwasende territories in the Orientale province. The Mai Mai Morgan group comprises of several dozen militias who operate in small groups. Additionally, there is the Mai Ma Simba, which is also known as "Armée Populaire de Libération Nationale CongolaiseLumumba - APLNC/Lumumba) led by "General" Mando Mazero and "General" Lucien Simba ${ }^{15}$. The Mai Mai Simba comprises of 150-200 militias and these operate in the Maniema and Orientale provinces. There is reportedly some deliberate collaboration in terms of armed activities between the Mai Mai Simba, and the elements from Mai Mai Morgan, the Congolese army, Raia Mutomboki and the Sheka militia groups ${ }^{16}$.

\section{Allied Democratic Forces (ADF)}

Another rebel militia group is the ADF which is a Ugandan-led Islamist rebel group operating in the northwest of the Ruwenzori Mountains around Beni Territory. The group, 
which was founded in the mid-1990s is led by Jamil Mukulu, a Christian turned Muslim. The ADF has an estimated strength of more than 2,000 combatants ${ }^{17}$. What makes the group relatively sophisticated and complex is its reported links to the international and regional the terrorist networks of Al-Qaeda and Al-Shabaab. The group has also been reported to be continuously recruiting Congolese youths in North-western DRC, particularly in the areas of Beni.

\section{Coalition des Groupes Armés de l'Ituri (COGAI) and Its Allies}

This rebel militia group was formed in mid-2012 with the objective of uniting those militias operating in the Ituri district in the Orientale Province. It is led by "Brigadier-General" Justin Banaloki (alias Cobra Matata). With an estimated strength of 800 men, the group controls parts of the eastern and southern Irumu territory in Ituri ${ }^{18}$. An allied militia group to COGAI is the Forces de resistance patriotiques en Ituri (FRPI). The FRPI is led by Cobra Matata. Whilst efforts have been made to try and integrate the FRPI into the Congolese army, little progress has been made in that regard. The rebel militia group's main thrust has been to reach an agreement with the Kinshasa government where its general political and military concerns would be addressed. The other group, Kata Katanga ("cut off Katanga" in Swahili), is a loosely structured armed group comprising individuals and groups campaigning for the secession of DRC's south eastern Katanga Province. The group is led by Kyungu Mutanga and it operates in the areas of Manono, Mitwaba and Pweto in south eastern Congo ${ }^{19}$.

\section{Forces de Défense Nationale (FDN) and Some New Offshoots}

The FDN militia group was created by Congolese soldiers who defected from the national army in 2010, over perceived marginalization in terms of promotions and other benefits. The FDN's estimated strength is about 160 armed militias. It operates in the eastern Walikale Territory. Whilst there have been reports of desertions from the FDN, a new group which was formed in October 2012 (the M18 armed militia) has been operating in north eastern DRC. It is further reported however, that in addition to the M18, another group (the M26) was created in October 2012.

The various armed groups have been carrying out atrocities in eastern DRC. The sources of political and military support have been varying. There have been allegations of internal and external support for these militias. Accusations and counter accusations have been traded between the Congolese government and the neighbouring countries and even beyond about the covert and overt political and logistical support for these armed militia groups.

When the Security Council came up with Resolution 2098, it was this Resolution which extended MONUSCO's mandate and created the FIB to conduct offensive operations (against the above-mentioned militias) within the MONUSCO's area of responsibility ${ }^{20}$. The Brigade was mandated by the UNSC to undertake peace enforcement (not peacekeeping) 
The United Nations Force Intervention Brigade: Wither the SADC/ICGLR Synchronised Peace Support Efforts in the Eastern Democratic Republic of Congo Recurring Conflict?

responsibilities $^{21}$. These responsibilities include offensive operations against armed rebel groups by the brigade as a single entity or jointly with other units of the Congolese Armed Forces (FARC).

\section{The General Challenges to the Effective Operations of the Force Intervention Brigade}

Despite the counter offensive operations against the armed groups in eastern DRC, the FIB has continued to encounter challenges. They range from political and strategic to operational constraints. The political challenges that the brigade has encountered and perhaps will continue to encounter revolve around the issue of who calls the shots in terms of determining the modus operandi of the Force and what inclination the mission is supposed to take. International state actors such as the European Union (EU), the US, the UK, France and Belgium have been "supporting partners" to the framework of cooperation between the ICGLR and the SADC. From the authors' viewpoint, the covert and overt interests of these international state actors may arguably militate against or even complicate the political unity of purpose among the member states of these two groupings. At the time of writing this article, the political and diplomatic relations between these international state actors and some members of both the ICGLR and the SADC, have not been sound or cordial. In fact the relations between some ICGLR and SADC member states have been hostile.

Notable examples include all the above mentioned international state actors' relations with the DRC, Burundi, Rwanda, (recently South Sudan), Uganda and Zimbabwe among others $^{22}$. One would argue that the unsound relations between these international state actors and some members of the ICGLR and the SADC will affect the commonality of regional interests and coordination in terms of the relevant political support and direction which are needed by the two groups in as far as utilising the FIB as a peace enforcement mechanism is concerned.

The strategic constraints revolve around factors such as MONUSCO's relations with the DRC government and the FIB's mandate. Prior to the deployment of the brigade, MONUSCO personnel have been operating in coordination with relevant DRC government institutions. The notable collaboration has been that between MONUSCO peacekeeping troops and FARC. However, relations between MONUSCO and the DRC government have soured as a result of allegations and counter allegations against human rights abuses and interference in the internal affairs of the DRC government. Taking into cognisance that the FIB was deployed and operates within the confines of MONUSCO, this situation creates a complicated predicament for the intervention force in terms of strategic cooperation between FIB troops and FARC. Even if there is sound cooperation between FIB and FARC, the likelihood of covert support by MONUSCO to the armed groups cannot be ruled out. Another strategic predicament that the FIB has encountered is that of the mandate. The UNSC Resolution 2098 authorises the Force to take all necessary measures that will neutralise the capacity of armed groups to threaten human security in eastern Congo $^{23}$. Resolution 2089 
also states that these measures can be taken unilaterally by the FIB or jointly with the FARC $^{24}$. FIB's joint operation with FARC has thus resulted in it being of the eastern Congo conflict. Such developments have put the FIB in a strategic quagmire.

The Force has continued to encounter operational and tactical hiccups. Worth mentioning are the logistical constraints. Troop contributing countries have not been able to meet the logistical requirements for the operational efficiency and effectiveness of their respective contingents that form part of the Intervention Force. As a result of this relative lack of logistics, there have been some manoeuvres by state and non-state actors to try and utilise this loophole in order to influence the operational modus operandi of the Force.

Apart from the logistical challenges, the Intervention Force comprises of three contingents that use different operational and tactical doctrines. This difference and non-interoperability among the FIB's contingents affect its operational and tactical effectiveness in undertaking its mandate. Language barriers between the FIB personnel particularly operational commanders and the local Congolese populace had a great negative impact especially during early 2013 when the Force was deployed. Perhaps with the exception of some troops from the Tanzanian contingent, who could converse in one of the local languages (Kisiwahili), the language barrier had an effect on the operational and tactical efficiency of the troops from Malawi and South Africa.

\section{The ICGLR and SADC's Synchronised Regional Peace Enforcement Efforts: Any Impact on the Effectiveness of the Force Intervention Brigade?}

The synchronised regional peace enforcement efforts between the ICGLR and the SADC in support of the FIB's strategic, operational and tactical effectiveness must be formed on the basis of the Peace and Security Framework. As already alluded to, recurring armed conflicts in eastern Congo falls within the two regional groupings' areas of peace and security responsibilities. Some countries have dual membership in both the ICGLR and the SADC. In the case of the ICGLR, it is important to note that membership is categorised in terms of "activeness and non-activeness." Most SADC member states are non-active members of the ICGLR. It is therefore, prudent to discuss the ICGLR and the SADC synchronised regional peace enforcement efforts and the impact of this synergy on the effectiveness of the Force ${ }^{25}$. At the political level, the ICGLR and the SADC must make efforts at ensuring that member countries cooperate within the confines of the two regional groupings' collaborative peace and security interests. The respective ICGLR and SADC member countries have varying national self-interests. It was noted earlier on that some international state actors, notably the EU, the US, the UK, France and Belgium have been "supporting partners" to the framework of cooperation between the ICGLR and the SADC. Whilst some member nations in these two regional groupings have sound and even intimate political and diplomatic relations with these partners, the opposite could be said with regards to relations between other ICGLR and SADC members and these international state actors. It is prudent therefore, for the two groupings to come up with workable political initiatives and mechanisms that will drive or 
The United Nations Force Intervention Brigade: Wither the SADC/ICGLR Synchronised Peace Support Efforts in the Eastern Democratic Republic of Congo Recurring Conflict?

motivate member nations towards commonality of regional peace and security interests. Support from international states (the AU, the UN, the EU and others - even non-state actors) must always be in line with the two groupings' interests. Such political synergy would go a long way in making a positive impact on the effectiveness of the FIB.

As noted earlier on, the UNSC Resolution 2098 authorises the Force to take the necessary measures to neutralise the capacity of armed groups in eastern DRC which threaten human security. The fact that these measures can be taken unilaterally by the FIB or jointly by the FIB and FARC has resulted in the former being labelled as part to the conflict, thus putting the Force in a complicated predicament viz the undertaking of its mandate. Faced with such a predicament, there is need for the ICGLR and the SADC relevant institutions to rework and refine the framework of the mandate and mechanisms of the Force. The mandate and force composition (including the aspects of what each given member country should contribute) must be determined by the strategic institutions of the ICGLR and the SADC. In addition to political and strategic coordination and cooperation, the ICGLR and the SADC need to extend their synergy to the operational and tactical efforts of the FIB. It has been noted that the current troop contributing countries have less capacity to meet logistical requirements that will enhance the operational efficiency and effectiveness of their respective contingents that form part of the Intervention Force. Therefore, there is a need for the ICGLR and the SADC to mobilise resources as well as reinforce the brigade with additional contingents from member countries. In their efforts at mobilising resources and reinforcing the Force, the two regional groupings must be cautious when making a cost benefit analysis in any given cooperation and logistical support from international state and non-state partners.

The ICGLR and the SADC must take initiatives for joint-field training exercises by the contingents from the two groupings. Collaborative research and development by relevant think tanks and training institutions from the ICGLR and the SADC must be undertaken. The main thrust of these research and development initiatives would be to synergise on workable operational and tactical doctrines for the two regions' forces. It is the same training institutions in these two regions that should engage in short, medium and long-term language courses such as French, English, Portuguese and Swahili among others. Such courses, which can be undertaken on an exchange programme basis, would enhance the communication efficiency of the rank and file of those troops which form a part of future contingencies of a peace enforcement intervention force of this nature.

A critical advantage of the synchronised regional peace enforcement efforts between the ICGLR and the SADC is the fact that African regional organizations have gained considerable scope in peacekeeping and peace enforcement, notably ECOWAS and SADC (Tavares, 2011). Tavares (2011) notes that these two African sub-regional blocs have acquired considerable significant experience in military interventions in Liberia, Sierra Leone, Guinea Bissau, Ivory Coast, Lesotho and the DRC. However, Tavares also concludes that "African states participate in military interventions for reasons of national and personal interests rather than humanitarian reasons or out of a primary interest in preserving 
regional stability" (2011). All things considered, African directed peacekeeping like the UN Intervention Force in the DRC has more pros than cons. In the final analysis, the success and failure of peacekeeping formations ultimately depend on local and adjacent regional actors. The experience in Somalia in the 1990s, for instance, shows that any form of peacekeeping cannot succeed if local or regional actors are not leading the process. A number of African countries such as Zimbabwe which contributed peacekeepers in UNOSOM 1 and 11 performed extremely well when compared to some powerful external players.

\section{Conclusion}

This paper briefly discussed the political and strategic security dynamics surrounding the UN FIB in undertaking its mandate from the time it was deployed in eastern Congo up to the third quarter of 2016. The paper's main thrust has been on the possible SADC/ ICGLR synchronised peace support efforts in the eastern Congo recurring conflicts with reference to the utilisation of the Force. An examination was made with regards to how the quest for synchronised peace enforcement efforts by the ICGLR and the SADC has been compromised by the respective self-interests of international actors. It was noted that the Force has so far encountered (and continues to encounter) a number of constraints which have regional and international inclinations. The eastern Congo conflict is an area of peace and security responsibility for both the SADC and the ICGLR. Thus, it was generally recommended that the two groupings' relevant political and strategic security institutions need to continuously make synchronised efforts towards workable mechanisms for the utilisation of the Intervention Force in eastern DRC or any future peace enforcement initiative that calls for the synergy of the ICGLR and the SADC.There is every reason to assume that contemporary peacekeeping operations should be driven or at most directed by sub-regional actors than the traditional military interventions which are directed at the behest of some major Western powers as was the case in Somalia and Operation Turquoise.

\section{End Notes}

${ }^{1}$ As noted by Major General Patrick Cammaert (Rtd.), former military advisor in the United Nations Department of Peacekeeping Operations and former Eastern Division commander of the UN Mission in the Democratic Republic of Congo, the UN Force Intervention Brigade was originally conceived by the International Conference of the Great Lakes Region (ICGLR) with the support of the African Union (AU) and the South African Development Community (SADC). See Maj Gen Cammaert Issue brief on "The UN Intervention Brigade in the Democratic Republic of Congo", International Peace Institute, July 2013; http://reliefweb.int/sites/reliefweb. int/files/resources/The\%20UN\%20Intervention\%20Brigade\%20in\%20the\%20Democratic\%20Republic\%20 of\%20the\%20Congo.pdf (accessed 25 July 2016).

2. See the Security Council SC/10964: Resolution 2098 (2013). See also S Sheeran and S case, 2014 The Intervention Brigade: Legal Issues for the UN in the Democratic Republic of the Congo https://www. ipinst.org/wp-content/uploads/publications/ipi_e_pub_legal_issues_drc_brigade.pdf (accessed 20 July 2016).

${ }^{3}$ Fighters from the M23 rebel group have captured Goma, the main city in resource-rich eastern Democratic Republic of Congo. http://www.bbc.com/news/world-africa-20405739 (accessed 20 June 2016). 
The United Nations Force Intervention Brigade: Wither the SADC/ICGLR Synchronised Peace Support Efforts in the Eastern Democratic Republic of Congo Recurring Conflict?

${ }^{4}$ S Hofstatter, "South Africa at war in the DRC - The Inside Story" 22 August, 2014, http://www.timeslive. co.za/local/2014/08/22/south-africa-at-war-in-the-drc--the-inside-story, (accessed 22 July 2016).

${ }^{5}$ In the authors' viewpoint, the task of neutralising armed militias operating in eastern DRC seems not only challenging but very complicated too. Considering the number of these armed militias and their alleged covert and overt sponsorships they receive from external state and to some extent non-state actors, neutralising these militias sounds a less achievable task for the UN Intervention Force, especially with concerted political, strategic and operational support from relevant states and to some extent non-state institutions in the SADC and the ICGLR.

${ }^{6}$ Mutisi M, "Redefining Peacekeeping: The Force Intervention Brigade in the Democratic Republic of Congo", KUJENGA AMANI, The Social Science Research Council, 26 July 2015 (accessed 03 June 2016).

7 See The International Coalition for the Responsibility to Protect; https://icrtopblog.org/2015/01/16/anindispensable-protection-tool-assessing-the-force-intervention-brigade-in-the-drc (accessed 20 July 2016).

${ }^{8}$ See Chris Vogel “Congo: Why UN peacekeepers have a credibility problem”, www.theguardian.com/ world/2013/aug/30/congo-un-peacekeepers-problem, (accessed 10 July 2016).

${ }^{9}$ The UN Intervention Brigade was originally conceived by the International Conference of the Great Lakes Region (ICGLR) with the support of the African Union (AU) and South African Development Community $(\mathrm{SADC})$.

${ }^{10}$ See Maj Gen Cammaert Issue brief on"The UN Intervention Brigade in the Democratic Republic of the Congo", International Peace Institute, July 2013; http://reliefweb.int/sites/reliefweb.int/files/resources/The\%20 UN\%20Intervention\%20Brigade\%20in\%20the\%20Democratic\%20Republic\%20of\%20the\%20Congo.pdf (accessed 25 July 2016).

${ }^{11}$ It should be noted that neutralising and disarming these armed groups appear complicated a task for the FIB. There are political and strategic complexities surrounding the formation, modus operandi and support of these militias. Faced with the multiplicity of armed insurgent groups operating in various parts of eastern Congo, a synchronised and well-coordinated approach by political and strategic security institutions in both the SADC and the ICGLR will enhance the capacity of the Intervention Force in effectively undertaking its mandate (see Armed groups in eastern DRC, http://www.irinnews.org/report/99037/briefing-armed-groups-eastern-drc (accessed 20 July 2016); also see Armed Groups - Enough Project, www.enoughproject.org > Conflicts > Eastern Congo (accessed 20 July 2016).

${ }^{12}$ See armed groups in eastern DRC, http://www.irinnews.org/report/99037/briefing-armed-groups-eastern-drc (accessed 20 July 2016); also see Armed Groups - Enough Project, www.enoughproject.org > Conflicts > Eastern Congo (accessed 20 July 2016).

${ }^{13}$ See http://www.responsibilitytoprotect.org/index.php/crises/crisis-in-drc (accessed 25 July 2016).

${ }^{14}$ See http://www.enoughproject.org/conflicts/eastern_congo (accessed 25 July 2016).

${ }^{15}$ See armed groups in eastern DRC, http://www.irinnews.org/report/99037/briefing-armed-groups-eastern-drc (accessed 20 July 2016); also see Armed Groups - Enough Project, www.enoughproject.org > Conflicts > Eastern Congo (accessed 20 July 2016).

${ }^{16}$ See armed groups in eastern DRC, http://www.irinnews.org/report/99037/briefing-armed-groups-eastern-drc (accessed 20 July 2016); also see Armed Groups - Enough Project, www.enoughproject.org > Conflicts > Eastern Congo (accessed 20 July 2016).

${ }^{17}$ See http://www.enoughproject.org/conflicts/eastern_congo (accessed 25 July 2016).

${ }^{18}$ See http://www.enoughproject.org/conflicts/eastern_congo (accessed 25 July 2016).

${ }^{19}$ See http://www.responsibilitytoprotect.org/index.php/crises/crisis-in-drc (accessed 25 July 2016). 
${ }^{20}$ See http://www.responsibilitytoprotect.org/index.php/crises/crisis-in-drc (accessed 25 July 2016).

${ }^{21}$ See http://www.enoughproject.org/conflicts/eastern_congo (accessed 25 July 2016).

${ }^{22}$ See armed groups in eastern DRC, http://www.irinnews.org/report/99037/briefing-armed-groups-easterndrc (accessed 20 July 2016); also see Armed Groups - Enough Project, www.enoughproject.org > Conflicts > Eastern Congo (accessed 20 July 2016). Maj Gen Cammaert made a worthy observation that whilst (by then) MONUSCO troops already had the mandate to conduct offensive military operations, divergent interpretations of that mandate and a lack of strategic guidelines on the use of force have resulted in the creation of this new brigade. See Maj Gen Cammaert Issue brief on "The UN Intervention Brigade in the Democratic Republic of Congo", International Peace Institute, July 2013; http://reliefweb.int/sites/reliefweb.int/files/resources/The\%20 UN\%20Intervention\%20Brigade\%20in\%20the\%20Democratic\%20Republic\%20of\%20the\%20Congo.pdf (accessed 25 July 2016).

${ }^{23}$ See also Maj Gen Cammaert Issue brief on "The UN Intervention Brigade in the Democratic Republic of Congo", International Peace Institute, July 2013; http://reliefweb.int/sites/reliefweb.int/files/resources/The\%20 UN\%20Intervention\%20Brigade\%20in\%20the\%20Democratic\%20Republic\%20of\%20the\%20Congo.pdf (accessed 25 July 2016).

${ }^{24}$ See also Maj Gen Cammaert Issue brief on "The UN Intervention Brigade in the Democratic Republic of Congo", International Peace Institute, July 2013; http://reliefweb.int/sites/reliefweb.int/files/resources/The\%20 UN\%20Intervention\%20Brigade\%20in\%20the\%20Democratic\%20Republic\%20of\%20the\%20Congo.pdf (accessed 25 July 2016).

${ }^{25}$ International state actors, notably the US, the UK, France and many others ' relations with some countries in the SADC and the ICGLR such as DRC, Zimbabwe, Burundi, Rwanda, (recently South Sudan) and Uganda have not been sound at the diplomatic and political levels. In the context of this paper, there is less or no significant mention of the East African Community (EAC). The main thrust of the paper is on the synergy between the ICGLR and the SADC. The rationale behind this is that the ICGLR seem to have made a significant impact in as far as synchronised efforts with the SADC in dealing with the eastern Congo conflict is concerned.

\section{References}

Armed groups in eastern DRC. Retrieved from

http://www.irinnews.org/report/99037/briefing-armed-groups-eastern-drc

BBC. (2016). Fighters from the M23 rebel group have captured Goma, the main city in resource-rich eastern Democratic Republic of Congo. Retrieved from http://www. bbc.com/news/world-africa-20405739.

Cammaert, P. (2013, July). Issue brief. The un intervention brigade in the democratic Republic of the Congo. International Peace Institute. Retrieved from http:// reliefweb.int/sites/reliefweb.int/files/resources/The\%20UN\%20Intervention\%20 Brigade $\% 20$ in \%20the\%20Democratic\%20Republic\%20of\%20the \%20Congo.pdf.

Draper, G. I. A. D. (1963). The legal limitations upon the employment of weapons by the United Nations Force in the Congo. The International and Comparative Law Quarterly, 12 (2), 387-413.

Englebert, P., \& Tull, D. M. (2008). Post-conflict reconstruction in Africa: Flawed ideas about failed states. International Security, 32 (4), 106-139.

Gibbs, D. N. (2000). The United Nations, international peacekeeping and the question of 'impartiality': Revisiting the Congo Operation of 1960.The Journal of Modern African Studies, 38 (3), 359-382. 
Hirsch, J. L., \& R. B. Oakley. (1995). Somalia and operation restore hope. Washington, DC: US Institute of Peace.

Hofstatter, S. (2014). South Africa at war in the DRC - the inside story. Retrieved from http://www.timeslive.co.za/local/2014/08/22/south-africa-at-war-in-the-drc-the-inside-story.

Jackson, A. (2007). Conference Report: Peace support operations in Africa: A joint BritishKenyan initiative. African Affairs, 106 (425), 705-707.

The International Coalition for the Responsibility to Protect. (2015). Retrieved from https://icrtopblog.org/2015/01/16/an-indispensable-protection-tool-assessing-theforce-intervention-brigade-in-the-drc.

Mutisi, M. (2015). Redefining peacekeeping: The Force Intervention Brigade in the Democratic Republic of Congo. KUJENGA AMANI, The Social Science Research Council.

Ruggie, G. J. (1996). The United Nations and the collective use of force: Whither or whether? International Peacekeeping, 3 (4), 1-20.

Sheeran, S., \& Case, S. (2014). The Intervention Brigade: Legal issues for the UN in the Democratic Republic of the Congo. Retrieved from https://www.ipinst.org/wpcontent/uploads/publications/ipi_e_pub_legal_issues_drc_brigade.pdf

Tavares, R. (2011). The participation of SADC and ECOWAS in military operations: The weight of national interests in decision-making. African Studies Review, 54, (2), 145-176.

Tull, D. M. (2010). Troubled state-building in the DR Congo: the challenge from the margins. The Journal of Modern African Studies, 48, (4), 643-661.

Vogel, C. (2013). Congo: Why UN peacekeepers have a credibility problem. Retrieved from www.theguardian.com/world/2013/aug/30/congo-un-peacekeepers-problem. 